\title{
JAGTEN PÅ DEN HISTORISKE JESUS
}

\author{
Af Burton L. Mack
}

Begrebet om den historiske Jesus er en moderne videnskabelig forestilling om et formodet objekt, der er genstand for en uafsluttet søgen. Det henviser til det menneske, som Jesus må have været i modsætning til de billeder, som er gengivet $\mathrm{i}$ Det Nye Testamentes evangelier. Evangeliernes skildringer er fyldt med klart fantastiske træk. Religionshistorikere ville kalde disse træk mytiske. Der er varsler, profetier, undere, apokalyptiske åbenbaringer, engle, guddommelige røster, en jomfrufødsel, korsfæstelsen af en gudesøn, opstandelser, himmelrejser og forvandlingen af guds søn til et kosmisk væsen med magt til at regere verden som herre og konge. Selv om vi nedtonede nogle af disse skildringer som forståelige overdrivelser hos en endnu usikker bevægelse, der forsøger at afmærke sit eget omrâde, ville de mytiske træk ikke forsvinde. For det er alt, hvad der er i evangelierne. Hertil kommer, at evangeliets plot kun giver mening som fiktion. Det giver ikke mening som historie.

\section{Problemet}

Ifølge det tidligste evangelium, Markusevangeliet, som er skrevet omkring 75 e.Kr., dukker Jesus pludselig op i verden, hvor han er ude på en eller anden mission. Ved floden anerkendes han af Gud som hans søn og bemyndiges med guddommelig ånd. Han går ind i Galilæa og bekendtgør straks en ny orden kaldet Guds kongedømme. Dernæst går han ind $\mathrm{i}$ synagogen $\mathrm{i}$ Kapernaum blot for at møde en mand med en uren ånd (læs dæmon). Den urene ånd skriger: »Hvad har vi med dig at gøre, Jesus fra Nazaret! Er du kommet for at ødelægge os? « (Mark 1,24). Det implicitte svar er: »Ja, absolut!« Folket reagerer med at sige: »Hvad er dette? En ny lære med myndighed! Selv de urene ånder befaler han over, og de adlyder ham!« $(1,27)$. Ordet er eksousia, bemyndigelse til at udføre befalinger. Folket er fascineret over denne utrolige koncentration af magt og renhed i Jesu person. Gud, synes det, har et udestående af kosmiske og apokalyptiske dimensioner med 


\section{Jagten på den historiske Jesus}

det jødiske establishment. Ifølge Markus' fortælling tager det ikke lang tid for de skriftkloge, farisæerne, herodianerne og ypperstepræsterne at fatte pointen. Sammen planlægger de at slippe af med Jesus, og da Jesus senere af uforklarlige årsager - beslutter sig for at tage til Jerusalem for, som han forklarer sine disciple, at $\mathrm{d} \varnothing$ som en martyr for sin egen sag, bliver han faktisk slået ihjel af ypperstepræsterne i forbund med romerne. Ifølge Markus fremskynder denne handling mod Guds søn, den retmæssige arving til Guds kongedømme, på den ene side den jødiske tempelstats sammenbrud, og stiller på den anden side uret for en eskatologisk ødelæggelse af ethvert menneskeligt kongedømme, når Jesus vender tilbage med magt til at hævne og til at etablere Gudsriget.

Som enhver burde kunne se, er denne fortælling usandsynlig som historie. Den er mættet af myte, og den er ondskabsfuld som fortælling om guddommelig hævn over folk, som dræbte Guds søn uden at vide, hvad de gjorde. For den historiker, som ikke er bundet af en teologisk dagsorden, kan det umuligt have været de begivenheder, som er fortalt $i$ evangeliet, der igangsatte Jesus-bevægelsen. Men det gjorde de heller ikke. For det første er der intet vidnesbyrd om, at de, som fulgte Jesus, havde en sådan fortælling $i$ tankerne i de første 45 år. For det andet kan man først have forestillet sig dette plot efter den romersk-jødiske krig fra 66 til 73 e.Kr. Hvorfor det? Fordi fortællingens logik ikke fungerer uden at ophæve tiden mellem Jesus i 20 'erne og $\varnothing$ delæggelsen af templet i 70 e.Kr. Forskere af min observans ser nu Markus' fortælling som resultatet af en meget smertelig diskussion inden for en meget forvirret Jesus-bevægelse, der ikke længere var sikker på sit anliggende. Disse mennesker var forvirrede, fordi forskellige dele af bevægelsen havde indtaget afgørende forskellige positioner angående hvis side, de skulle være på under krigen. Og de var bekymrede, fordi de fandt sig selv kastet rundt $i$ en efterkrigsverden, der var uimodtagelig for deres udtjente budskab. Ikke desto mindre udvirkede fortællingen undere inden for Jesusbevægelsen, idet den gjorde rede for deres trængselstid og forklarede, hvorfor det perfekte kongedømme måtte se sig udskudt. Det varede ikke længe, før denne fortælling blev noget af en vinder, i stand til at tiltrække sig andre Jesus-gruppers opmærksomhed. De andre evangelier, som blev skrevet senere, på andre steder, af andre forfattere og uafhængigt af hinanden - Matthæus, Lukas og Johannes samt andre, som ikke er medtaget i Det Nye 
Testamente - brugte alle Markusteksten som grundlag for deres handlingsgang. Hver enkelt ændrede rigtignok fortællingen lidt for bedre at kunne se deres eget samfund afspejlet $i$ de oprindelige instruktioner. Men ingen af dem slettede det markinske plot. De ændrede fortællingen ved simpelthen at nedtone den fornemmelse af presserende karakter, som kendetegner Markusfortællingen, og ved at tilføje andre mytiske træk, der både kunne udvide den kosmiske horisont $\mathrm{i}$ og den episke betydning af det markinske drama. Og således fandt evangelierne endelig deres plads som den kanoniske beretning om den kristne oprindelse til den vestlige kulturs lange historie.

Indtil oplysningstiden var den Jesus, som er skildret $\mathbf{i}$ evangelierne, og den historiske Jesus således en og den samme. Kristen mentalitet og forestillingsevne havde ikke svært ved at tænke sig evangelierne som historier eller beretninger om, hvordan ting virkelig måtte være sket. Men henimod slutningen af det 18. århundrede begyndte forskere at undre sig, og en søgen efter den historiske Jesus, en sandsynlig person, der kunne skelnes fra evangeliernes Kristus, blev et hovedmål inden for nytestamentlig forskning. To hundrede år er en temmelig lang tid at vie til et sådant projekt. Man skulle mene, at der med en sådan fælles bestræbelse efterhånden måtte være opnået en konsensus. Som I ganske sikkert ved, er dette desværre ikke sket. Vi har ret til at spørge hvorfor.

Der kan kort næunes tre grunde. Den første er, at forskerne ind til for nylig kun havde de data, som var givet med netop de evangelier, som de forsøgte at se bort fra. Det krævede detaljerede studier at afgøre, hvilket evangelium der var det første, hvilke fortællinger i det første evangelium der var erindringstraditioner fremfor senere indbildninger, og hvorledes den menneskelige forestillingsevne fungerede $\mathrm{i}$ den græsk-romerske verdens kulturer, når den funderede over erindringer. At skelne mellem myte og historie $\mathrm{i}$ evangelietraditionen, en usædvanligt sammenviklet lagdeling af erindring og fantasi, har været en meget vanskelig opgave.

En anden grund til det mislykkede resultat var, at forskerne ledte efter noget, der lignede en biografi om den historiske Jesus. Evangelierne var biografiske, og det syntes kun naturligt for forskere i det 19. og 20. århundrede, at de tidlige kristne havde husket Jesus ved at skrive en biografi. Det er den måde, hvorpå store mænd altid er blevet husket, er det ikke? Og således blev denne søgen først og fremmest et forsøg på at finde den sande 


\section{Jagten på den historiske Jesus}

fortælling bag den mytiske fortælling, idet man mente, at kun en biografi over den historiske Jesus kunne bruges. Resultatet er den velkendte række af fremstillinger af Jesu liv, som dokumenterer den nytestamentlige forsknings historie og fortsætter med at blive skrevet. Men eftersom evangeliets plot er fiktion, kan denne fremgangsmåde ikke fungere og burde ikke længere anvendes.

En tredje grund til, at det ikke er lykkedes at nå frem til en konsensus om, hvordan den historiske Jesus må have været, er mere følsom. I det store og hele har de nytestamentlige forskere udøvet deres arbejde som kristne. De har derfor ikke været immune over for kristen, mytisk mentalitet, den ritualiserede, internaliserede og automatiske mekanisme, som kendetegner den kristne forestillingsevne, der hele tiden vender tilbage til de grundlæggende begivenheder for at genantænde den kristne vision og tro. Det er som om de i evangelierne fortalte begivenheder, som man forestiller sig som noget, der virkelig er sket, stadig besidder den gnist af guddommelig manifestation og magt, som frembragte og fortsætter med at frembringe kristen sandhed og erfaring. De fleste nytestamentlige forskere har trods alt forstået sig selv som teologer og bibelfortolkere så vel som historikere, der udtænkte kritiske metoder, hvormed charter-dokumentets kernebetydning og aktuelle budskab lod sig skelne. Således er en søgen efter den historiske Jesus ofte blevet forvekslet med en søgen efter kristendommens oprindelse, og denne søgen efter kristendommens oprindelse har altid været kendetegnet ved en søgen efter den oprindelige anledning til den kristne religion. Det er som om man har forestillet sig, at fundet af den historiske Jesus ville hidkalde et moment af definitiv klarhed, et rensende og åbenbarende moment, en oplevelse af »at møde Jesus igen for første gang«, som en nylig bog af Marcus Borg udtrykker det. Dette bør fremkalde et smil eller to, for Borg er klart et eksempel på en forsker, der fortsætter med at tænke mytisk. Hans argumentation og invitation er afgjort ikke værdig for en akademisk uddannet religionshistoriker. Ikke desto mindre er det netop denne jagen efter det magiske moment ved kristendommens begyndelse, der antages at bestå i mysteriet om Jesu fremtræden $\mathrm{i}$ den menneskelige historie, som igen og igen har blokeret for forskernes søgen efter den historiske Jesus.

Resultatet er blevet, at de roller, som de nytestamentlige forskere har tiltænkt den historiske Jesus, uvægerlig er blevet hentet fra dette eller hint 
træk ved evangeliernes Jesus. De fleste af disse roller er kun ubetydeligt mindre fantastiske end billedet af Jesus som et guddommeligt menneske og en gudesøn. Fra selskabsdyr til dommedagsprofet, de Jesus'er, som har spankuleret forbi forskernes $\varnothing \mathrm{jne}$, omfatter magiker og mystiker, undergører og guddommelig seer, inspireret religiøs reformator og apokalyptisk profet, guddommelig vismand og medfølende Messias - alle har været opfattet som udstyret med tilstrækkelig karisma (eller guddommelig kraft) til at kunne grundlægge den kristne religion med et slag. Det er som om den kristne oprindelse ikke lader sig tænke uden en ekstraordinær foranledning i begyndelsen, en særlig Jesus med overnaturlige egenskaber, uanset hvor subtilt de måtte være manifesteret.

For nylig er et blødt fokuseret billede af en sandsynlig historisk figur, der adskiller sig bemærkelsesværdigt fra evangeliefortællingens, imidlertid begyndt at tone frem. Forskere har været $\mathrm{i}$ stand til at identificere et ganske stort tekstmateriale fra de tidlige Jesus-bevægelser, før der forelå et narrativt evangelium. Dette materiale består for størsteparten af udtalelser, maksimer og læresætninger, hvor meget af det er samlet i den form for græsk-romersk antologi, der kaldes en gnomologi, eller en håndbog $\mathrm{i}$ belæringer og vise råd, og som tilhører en populærfilosofisk skole. Noget af dette lærdomsmateriale stammer fra et meget tidligt tidsrum, perioden af de første femogtyve år, da Jesu tilhængere var travlt optaget af at diskutere hans ideer og formulere et sæt af læresætninger, der var egnede for den bevægelse, som de havde tilsluttet sig.

Fra denne periode har vi nu 1) en samling af anekdoter om Jesus, der kaldes udsagnsfortællinger; ${ }^{1}$ 2) en rekonstrueret tekst bestående af Jesus-ord, den såkaldte $\mathrm{Q}$ (fra det tyske Quelle, der henviser til teksten som »kilde« til de Jesus-ord, der optræder i Matthæus og Lukas); 3) tidlige lag af visdomsord i det ikke-kanoniske Thomasevangelium; 4) nogle lignelser af Jesus; og 5) en eller anden gruppe af Jesus-tilhængeres oprindelsesmyte, som helt er sammensat af en lille mængde af særligt udvalgte og bevidst symbolske underfortællinger. Voila! Jesu belæringer er overhovedet ikke gådefulde. De er ganske på linie med andre populærfilosofiske skoletraditioner, som florerede i den græsk-romerske periode. De Jesus-tilhængere, som kultiverede disse lærdomme, viser sig således at være normale menneskelige væsener. Og det ekko, der lyder af Jesu stemme i disse håndbøger, angiver, at også 


\section{Jagten på den historiske Jesus}

han må have været et almindeligt menneske. Hans stemme er en lærers stemme, den type lærer, som i oldtiden opsøgte landsbyens markedsplads. Og at dømme ud fra hans undervisnings indhold og stil, som er meget tæt på en særlig populær form for samtidig filosofi, kunne han blandt almindelige mennesker være blevet betragtet som en slags kynisk filosof, en lærer der vovede at foreslå en modkulturel livsstil som det rette svar på den udfordring, der lå $i$ at leve $i$ en sammenblandet, flerkulturel verden.

Min plan for denne forelæsning er at præsentere jer for nogle data $\mathrm{i}$ de tidligste lag af Jesus-traditionen og bede jer betragte dem som et vidnesbyrd om, at det er muligt at forstå Jesus som en lærer af kynisk tilsnit. Jeg vil ikke være i stand til at redegøre for alle de kritiske studier og observationer, som er nødvendige for at afgrænse dette materiale. Jeg bliver nødt til at antage, at I kender noget til »det synoptiske problem« (de intertekstuelle relationer mellem de første tre evangelier), til »tokildehypotesen« (at Matthæus og Lukas uafhængigt af hinanden anvendte to hovedkilder, da de udarbejdede deres evangelier, nemlig Markus og Q), til vigtigheden af Thomasevangeliet (en ikke-kanonisk tekst bestående af Jesus-ord, hvoraf 35\% har sammenfald med Q), og til det synspunkt, som deles af de fleste kritiske forskere, at Markusevangeliet blev komponeret ved at sammenbringe tidligere udsagn, fortællinger og myter om Jesus. Jeg ønsker at gå direkte til noget af det tidligste materiale, som vi har fra Jesus-bevægelserne, Jesu aforismer i Q og Jesu udsagnsfortællinger i Markus.

\section{Jesus-aforismer i $Q$}

Skønt forskerne i mere end hundrede år har kendt til Q som en del af løsningen på »det synoptiske problem«, er dette skrift først for nylig blevet studeret som en tekst med sin egen integritet og historie. Q blev alene betragtet som en »kilde" til de narrative evangelier, og man antog, at denne tradition gengav belæringer, som var givet af den person, der var skildret $\mathrm{i}$ evangeliefortællingen. For nylig har vi lært mere om skoletraditioner i den græsk-romerske verden, den måde, hvorpå lærdomme blev tillagt en grundlægger, og de måder, hvorpå en sådan lærer-grundlægger blev husket. Q ser ganske anderledes ud for os nu. Vi har været i stand til at rekonstruere en enkelt græsk tekst ud fra dobbelttraditionen i Matthæus og Lukas, at identificere dens genre, at analysere dens indhold, at spore dens samlings- og kom- 


\section{Burton L. Mack}

positionshistorie, og at rekonstruere den tidlige historie for den Jesus-bevægelse, som frembragte den. Det viser sig nu, at denne Jesus-bevægelse hverken havde eller behøvede en biografi om Jesus, slet ikke en, der fremstiller ham som en gudesøn, der lider martyrdøden. Hans lære var tilstrækkelig til at igangsætte en bevægelse, og denne bevægelse var i stand til at opretholde en gruppes indbyrdes loyalitet i flere generationer. Jeg har fortalt denne historie og givet en engelsk oversættelse af teksten i min bog The Lost Gospel.

$\mathrm{Q}$ er et vindue, der åbner ud mod et ganske livligt sceneri. Der er folk, som støder på hinanden i landsbyerne, på vejen, i hinandens hjem, og i byerne. Det er et billede af livet $i$ den offentlige arena $i$ Galilæa $i$ det første århundrede, og livet er bestemt som mødet med andre mennesker. Der er instruktioner om, hvordan man skal opføre sig under denne eller hin omstændighed, hvad man skal være på vagt for hos den anden, når man svarer på en eller anden måde, og hvad man skal mene om den sociale verden, hvori disse folk levede. Der er også en god del drilleri, truende parodier og direkte ford $\varnothing$ mmelse af dem, som afviser bevægelsen. De fleste af disse ord er aforistiske, mange stærkt metaforiske og nogle ganske gådefulde.

Ved første øjekast er der ikke megen mening $\mathrm{i}$ ordenes orden. Men så bliver det klart, at udsagnene falder $\mathrm{i}$ grupper, og at den sociale baggrund ændrer sig fra gruppe til gruppe. Ligesom de bagvedliggende omstændigheder ændrer sig fra en type af materiale til en anden, således skifter også belæringernes centrale indhold, og den retorik, som kendetegner materialets forskellige lag, afslører forskellige momenter eller stadier $i$ en åndsretnings historie og udvikling. Således viser $\mathrm{Q}$ sig at være en samling af ord, der er resultatet af en kompositionel og social historie, og tre distinkte lag eller stadier er blevet identificeret. Kun det tidligste lag har umiddelbar interesse for en søgen efter den historiske Jesus, og det interessante ved dette lag er, at det består af små enheder af ord, hvor ordsprogsagtig overlevering og stående eksempler samler sig omkring centrale aforismer. Dette indebærer, at aforismer må have været typiske for den tale, som kendetegnede Jesus og hans første tilhængere. Betragt venligst følgende: ${ }^{2}$ 


\section{Jagten på den historiske Jesus}

Hvor er de fattige heldige; Guds rige er deres. (Luk 6,20)

Den norm I bruger (til at dømme andre med), vil vare den norm, som bruges mod jer. (Luk 6,38)

Kan en blind lede en blind? (Luk 6,39)

Et godt træ bærer ikke dårlig frugt. (Luk 6,43)

Ræve har huler, og fugle har reder, men mennesker har ikke noget hjem. (Luk 9,58)

Enhver, som beder, får. (Luk 11,10)

Der er intet hemmeligt, som ikke skal afsløres. (Luk 12,2)

Livet er mere end maden. (Luk 12,23)

Legemet er mere end klæderne. (Luk 12,23)

Er I ikke mere værd end fuglene? (Luk 12,24)

Hvor jeres skat er, dér er jeres hjerte. (Luk 12,34)

De som ophøjer sig selv, vil blive ydmyget. (Luk 14,11)

Hvis salt har mistet sin kraft, så er det nytteløst. (Luk 14,34)

Ingen kan tjene to herrer. (Luk 16,33)

Disse udsagn er ikke usædvanligt blændende. Mange er ganske enkelt versioner af ældgammel ordsprogstradition, og alle rummer iagttagelser, der har brug for en livssituation for at blive rammende. Men de er temmelig krasse, lettere nedslående, men mildt humoristiske $\mathrm{i}$ den forstand, at indsigter vedrørende menneskers adfærd og begær er blevet presset helt ud i det yderste, for ikke at sige absurde. Vi kan bruge dem til at illustrere den aforistiske natur, som kendetegner den visdom, der er blevet tillagt Jesus. Og vi kan allerede fremhæve den pointe, at de strutter af den skarpe stil, som er karakteristisk for de kyniske maksimer og kortfattede udsagn. Den kyniske duft bliver endnu tydeligere, hvis vi til disse aforismer tilføjer en liste af formaninger, udsagn, der anbefaler en vis form for adfærd. Betragt venligst følgende: 


\section{Burton L. Mack}

Glæd jer, når man bebrejder jer. (Luk 6,22)

Velsign dem, der forbander jer. (Luk 6,28)

Slår nogen dig på den ene kind, så tilbyd ham også den anden. (Luk 6,29)

Giv enhver, som beder dig. (Luk 6,30)

Døm ikke, så skal I ikke selv dømmes. (Luk 6,37)

Tag først bjælken ud af dit eget øje. (Luk 6,42)

Lad de døde begrave deres døde. (Luk 9,60)

Gå ud som lam blandt ulve. (Luk 10,3)

Tag ikke pung med, ikke taske, ikke sko. (Luk 10,4)

Spis hvad man byder jer. (Luk 10,7)

Bed, så skal der gives jer. (Luk 11,9)

Frygt ikke. (Luk 12,7)

Vær ikke bekymrede for livet, hvordan I făr noget at spise, eller for, hvordan I făr tøj på kroppen. (Luk 12,22)

Sælg jeres ejendele og giv almisse. (Luk 12,33)

Hvorfor skønner I ikke ud fra jer selv, hvad der er det rette? (Luk 12,57)

I kan ikke være mine elever, hvis I elsker jeres foræeldre mere end mig. (Luk 14,26)

Disse udsagn lader os se, at Jesus-tilhæengerne tilsyneladende påtog sig, hvad vi ville kalde en alternativ livsstil. De efterlevede den både hjemme og på agoraen (torvet). Den offentlige arena var stedet, hvor man mødte mennesker, som levede efter konventionelle koder, og Jesus-tilhængerne gav sig tilsyneladende til kende med fuldt overlæg. Og deres opførsel fremkaldte visse gnidninger. Hvad de gjorde, blev betragtet som risikabelt, men umagen værd. Man blev rådet til at være forsigtig, men også modig. Pas på, lad være at bekymre jer. Vær kun sikker på, at I gør det. Men hvad var det præcis de gjorde og hvorfor?

Hvis vi analyserer de temaer, som igen og igen dukker op, fremtrader et program, der ser sådan ud: 


\section{Jagten på den historiske Jesus}

En kritik af de rige og deres besiddelser.

En kritik af hykleri og indbildskhed.

Frygtløshed over for dem, som har magt og autoritet.

En udfordring til at give afkald på det underlag, som almindeligvis

blev betragtet som nødvendigt for et menneskeliv.

Et kald til frivillig fattigdom.

Skik og brug i forbindelse med skamløst betleri.

Skik og brug i forbindelse med reaktion på offentlig bebrejdelse.

Afståelse fra gengældelse.

Frigørelse fra familiebånd.

En stærk følelse af uafhængigt kald.

Optagethed af personlig integritet og autenticitet.

En udfordring til at leve naturligt uden hensyn til omkostningerne.

En tiltro til den naturlige orden.

Målbevidst stræben efter Guds rige.

Tillid til Guds omsorg.

$\mathrm{Nu}$ har vi noget. Historikeren ville ikke have svært ved at genkende disse karakteristika. De udgør en samlet mængde, der bogstaverer et program. Og programmet svarer til kynikernes populære profil. I antikken spillede kynikerne en meget vigtig rolle som kritikere af de konventionelle værdier og undertrykkende ledelsesformer i næsten et tusind år, fra det femte århundrede f.Kr. til det sjette århundrede e.Kr. Deres populære filosofi frembragte figurer som Antisthenes, Diogenes, Krates, Bion; Thales; Meleager, Musonius, Rufus, Dio Chrysostomos, Demonax, Peregrinus Proteus, Sostratus og Theagenes - alle vigtige figurer $\mathrm{i}$ den græske tænknings historie. Deres evner og egenskaber spændte fra i fuld offentlighed at kunne udholde et liv $\mathrm{i}$ afholdenhed, over modet til at yde social kritik blandt højtstående (kaldet parresia, eller »talens frimodighed (frækhed)«), til den lærdom og det raffinement, som var krævet for at kunne være talsmand for det kyniske synspunkt på den litterære kompositions højeste niveau. Selv om de med rette 
var kendte for at være irriterende for dem, der levede på systemets præmisser og nød godt af privilegiernes, velstandens og magtens velsignelse, blev kynikerne højt respekteret for, hvad de havde opnået med hensyn til en skærpelse af selvtilstrækkelighedens (autarcheia) dyd (arete) midt i en usikker tid. Nogle forskere har sagt, at kynikerne betød det samme for polis, som de jødiske profeter betød for kongerigerne i Israel og Juda. Epiktets tredje tale er en bemærkelsesværdig afsløring af en stoikers højagtelse for kynikerens stilling som en væsentlig faktor i forsøget på at bevare et ærligt samfund under det romerske imperiums indbildte lykketid. Der er ikke noget $i$ listen over temaer, værdier og formaninger i det ældste lag af Q, som Epiktet ikke tilskriver kynikerne.

Konklusionen må blive, at andre ville have anskuet Jesus-folket som kynikere. De indtog en kritisk holdning over for det sociale livs normale mønstre. De overvejede de regler, som de fleste mennesker levede efter, regler, der hyldede begunstigelser, understøttede ranginddelinger og ansporede til hykleri. For at kritisere tingenes tilstand gjorde Jesus-folket sig til talsmand for en alternativ livsstil. "Hvorfor ikke leve på en anden måde?« »Hvorfor ikke vise dem, at det kan lade sig gøre? « De udviklede endog et filosofisk rationale til begrundelse for ikke at tage notits af konventionelle sociale overenskomster. Dette gjorde de ved at appellere til den måde, hvorpå Gud drog omsorg for den naturlige orden, noget der også var en mulig tanke for kynikerne. "Lev naturligt«, sagde begge, "Lad dig ikke lede af de regler, som lige nu styrer den sociale situation. Og lad være med at bekymre dig. Det er umagen værd at beskytte din egen personlige opfattelse af integritet.«

\section{Anekdoterne om Jesus (Chreiai)}

I Markusevangeliet er der mere end to dusin beretninger om Jesus, som vi kalder udsagnsfortællinger. Jesus er skildret i en særlig situation; en eller anden sætter spørgsmålstegn ved, hvad han siger eller gør; og Jesus giver et skarpt gensvar. I de fleste tilfælde er disse fortællinger forskønnet for at beskrive situationen på en ganske bestemt måde, forklare hvorfor spørgsmålene bliver rejst, karakterisere dem, som sætter spørgsmålstegn ved eller gør indsigelse mod Jesus, og måske for at give Jesus muligheden for at aflevere en kvik replik til sine modstandere inden han fremsætter det endeli- 


\section{Jagten på den historiske Jesus}

ge udsagn. Selvfølgelig får Jesus altid det sidste ord, et udsagn om situationen, hvorfra fortællingerne har hentet deres moderne betegnelse. Det er imidlertid ofte tilfældet, at den længere fortælling lader sig forkorte til den enkelte udveksling af udfordring og svar, der udgør den centrale chreia eller anekdote. Betragt følgende Jesus-chreiai, der kan sammenlignes med en hvilken som helst samling af kyniske anekdoter: ${ }^{3}$

(J-1) Da han blev spurgt, hvorfor han spiste sammen med toldere og syndere, svarede Jesus: »De raske har ikke brug for læge.« (Mark 2,17)

(J-2) Da Jesus blev spurgt, hvorfor hans disciple ikke fastede, svarede han: »Kan bryllupsgæster faste, mens brudgommen er sammen med dem? « (Mark 2,19)

(J-3) Da Jesus blev spurgt, hvorfor hans disciple plukkede aks på sabbatten, svarede han: »Sabbatten blev til for menneskets skyld, ikke mennesket for sabbattens skyld.« (Mark 2,27)

(J-4) Da man spurgte, hvorfor de spiste med urene hænder, svarede Jesus: »Det er ikke det, som kommer ind i et menneske, men det, som kommer ud af et menneske, der gør det urent.« (Mark 7,15)

(J-5) Da Jesus blev spurgt, hvem der var den største, svarede han: »Hvis nogen vil være den første, skal han være den sidste.« (Mark 9,35)

(J-6) Da nogen tiltalte ham som »Gode Mester«, svarede Jesus: »Hvorfor kalder du mig god?« (Mark 10,18)

(J-7) Da han blev spurgt, om en rig kunne komme ind i riget, svarede Jesus: »Det er lettere for en kamel at komme igennem et nåleøje.« (Mark $10,25)$

(J-8) Da nogen viste ham en mønt med kejserens præg og spurgte: »Er det tilladt at betale kejseren skat eller ej? «, svarede Jesus: »Giv kejseren, hvad kejserens er, og Gud, hvad Guds er!« (Mark 12,17) 


\section{Burton L. Mack}

(J-9) Da en kvinde i skaren råbte: »Saligt er det moderliv, som bar dig, og de bryster, du diede!«, svarede Jesus: „Salige er snarere de, som hører Guds ord og gør, hvad han siger!« (Luk 11,27-28)

(J-10) Da en i skaren sagde til Jesus: »Mester, sig til min bror, at han skal skifte arven med mig.«, svarede han: »Min herre, hvem har sat mig til at være jeres dommer eller sagfører? « (Luk 12,13-14)

Disse fortællinger er ganske lig et stort antal anekdoter fortalt om kynikerne. Den græske forkærlighed for friske formuleringer og glimrende gensvar var ikke forbeholdt kynikerne, men anekdoter af denne type var meget hyppigere i de sokratiske, kyrenæiske og kyniske traditioner end i nogen anden skoledannelse. Blandt stoikerne var etiske maksimer og truismer for det meste regelen. Nogle som var modige nok til at stå op imod dem og udfordre dem til kamp synes at have leget med kynikerne. Eftersom disse levede i en slags negativ symbiose med samfundet, idet de gav udtryk for ligegyldighed, men faktisk var afhængige af det, ville næsten enhver typisk situation kunne omformes til en fælde. Tricket bestod $i$ at fange kynikeren $i$ et eller andet uforvaret kompromis og dernæst påpege hans manglende evne til at opnå uafhængighed af samfundet. Kynikerne solede sig i disse møder, som de tog som en lejlighed til at afsløre normale forventninger som latterlige. Og anekdoten var et perfekt medium for uddestillering af sådanne udvekslingers natur. For at vinde måtte kynikeren anlægge et ganske anderledes synspunkt på tingene. Strategierne spændte fra vittig nedgøring over lærd iagttagelse og indsigt og bidende sarkasme til knusende selvironi, men altid med et strejf af humor for at tage lidt af stødet. Her er nogle eksempler: ${ }^{4}$

(K-1) Da han blev dadlet for at have omgang med slette personer, svarede Antisthenes: »Lægerne passer jo også deres patienter uden selv at få feber.« (DL 6,6)

(K-2) Da nogen sagde til Antisthenes: »Mange hylder dig. «, svarede han, »Hvorfor det, hvad har jeg gjort galt?«(DL 6,8) 


\section{Jagten på den historiske Jesus}

(K-3) Da en ville studere hos ham, gav Diogenes ham en fisk at bære og bad ham om at følge efter sig. Da studenten snart blev grebet af forlegenhed og smed den væk og gik bort, lo Diogenes og sagde: "Vort venskab blev ødelagt af en fisk.«(DL 6,36)

(K-4) »De fleste mennesker «, sagde Diogenes, »er så tæt på vanviddets rand, at en finger kan gøre hele udslaget. Hvis du går rundt og stritter med din langemand, vil folk tro du er skør, men ikke, hvis det er med lillefingeren.«(DL 6,35)

(K-5) Da nogen kritiserede ham for at besøge urene steder, svarede Diogenes, at også solen skinner ind på lokummerne uden at blive belortet. (DL 6,63)

(K-6) Da han blev spurgt, hvorfor han tiggede fra en statue, svarede Diogenes: "For at $\emptyset$ ve mig i at blive afvist. (DL 6,49)

(K-7) Da en spurgte ham, om han skulle gifte sig, svarede Bion: »Hvis din kone er grim, vil hun blive dit banesår; hvis hun er smuk, så vil du ikke kunne beholde hende for dig selv.« (DL 4,48)

(K-8) Krates erklærede, at vanære og fattigdom var hans fødested, et land, som skæbnen aldrig kunne underlægge sig. (DL 6,93)

(K-9) Da en af hans studenter sagde til ham: »Demonax, lad os gå hen til Asklepiet og bede for min $s ø n «$, svarede han: „Du må mene, at Asklepios er stokdøv, siden han ikke kan høre vore bønner herfra, hvor vi befinder os. " (Lukian, Demonax)

Grækerne vurderede et svar på dets humor og begavelse, to kvaliteter, som begge involverede en vis logik, der tillod kynikeren at slippe uskadt af krogen. De franske klassiske filologer Marcel Détienne og Jean-Pierre Vernant har brugt termen metis, eller behændig intelligens, om den form for listig visdom, der kræves. Medens sophia var den visdom, som var velegnet til begrebssystemer og stabile ordener, var metis det vid, som var påkrævet i 
tilfældige og farlige situationer. Metis var den visdom, som blev praktiseret af retorer, læger, navigatører, skuespillere og af enhver anden, der så sig truet af stærkere kræfter eller modstandere. Metis var den evne, der krævedes for at kunne tage bestik af situationen, bøje sig for de indvirkende mag. ter, foregive at være fanget $i$ en fælde, men dernæst pludselig skifte position for at unddrage sig eller, hvis man er heldig, for at få rollerne byttet om og få overtaget. I tilfældet netkamp (en af grækernes favorit-metaforer) ville den svage part for eksempel foregive sårbarhed, vente på modstanderens overmodige angreb, dernæst gribe hans net og kaste det tilbage over ham selv. Den kyniske anekdote er et fortræffeligt eksempel på metis inden for genren slagfærdige svar.

Logikken virker på følgende måde. En særlig omstændighed kræver kynikeren til regnskab (K-5): hvordan kan du opsøge steder, som er socialt uacceptable (næsten sikkert en eufemisme for horehuse)? Det første træk bestod $i$ at bestemme det stridspunkt, der gemte sig i udfordringen. I dette tilfælde var det ideen om at blive »forurenet« ved at besøge et »urent« sted, dvs. et socialt uacceptabelt sted. Det næste træk bestod i at skifte fokus og finde et eksempel på »besøge urene steder«, hvor besmittelse ikke optræder. For eksempel »besøger « solen lokummer uden at blive tilsmudset. Den smarte mangel på overensstemmelse mellem de to tilfælde af bes $\emptyset \mathrm{g}$ på urene steder fremkalder humoren. Eksplicit belæring var ikke målet. Samtalepartneren gik ikke bort for at tænke dybt over teorier om rene og urene ting. Men han kan meget vel være blevet overmandet af latter og have ladet kynikeren gå sin vej, eller måske ligefrem have forståtet pointen om den arbitrære natur af kategorien »uren«, når denne anvendes på et særligt socialt tilfælde. Hvad kynikeren angår, som tog imod udfordringen og var i stand til at håndtere en momentan forvirring i situationens logik, så havde han nu fri bane og var klar til endnu et sammenstød med sin sociale verdens konventioner.

De anekdoter, som er tilskrevet Jesus, virker efter den samme logik. I hvert tilfælde er en kynisk drejning karakteristisk for Jesu gensvar. Fndringen i diskursens ordener lader sig let identificere. I J-1 bliver spørgsmålet om besmittelse underløbet ved at skifte fra måltidskoder til medicinsk praksis. Det ligner, hvad der sker i anekdoten om Antisthenes i K-1. I J-2 vedrører diskrepansen en tid for faste og en tid, hvor dette er uhørt. J-3 hviler på en skelnen mellem to sabbatsregler, den ene som påbud og den anden 


\section{Jagten på den historiske Jesus}

som tilladelse. I J-4 er uoverensstemmelsen fremkaldt af sammenstillingen af måltidskoder med skatologiske iagttagelser. Den svarer til Diogenes' svar i K-5, der hviler på forskellen mellem social og naturlig kontamination. Nedgøringerne i J-5 og J-6 hviler på en fælles kritik af sociale værdier, som er knyttet til klasser. Udtrykkenes tvetydighed er med fordel brugt i kontrastudsagn, meget lig med det, som findes i Antisthenes' svar i K-2, da han blev fortalt, at han blev hyldet af mange. I J-7 er der to drejninger. Den ene er skiftet fra spørgsmålet om evner til en betragtning over vanskeligheder, der således synes at sige $\mathrm{ja}$, den rige kunne være $\mathrm{i}$ stand til at komme ind $\mathrm{i}$ kongeriget. Men den anden består $i$ at benytte et eksempel på vanskeligheder, der er så lattervækkende, at det svarer til at sige nej, der er ingen mulighed. I J-8 forbindes den politiske (lovbestemte) orden og den religiøse (naturlige) orden til en spændingsfuld knude. Som sådan er svaret lig med Bions svar på spørgsmålet om ægteskabet i K-7. I J-9 er to forestillinger om velsignelse kontrasteret, men dernæst forvekslet gennem et skift $\mathrm{i}$ de sociale relationers orden, som er på tale. Og Jesus-anekdoten i J-10 er ganske lig med at stort antal kyniske anekdoter, $i$ hvilke en student barsk bliver irettesat på grund af en misforståelse og henvist til sin egne muligheder for at se sagerne klarere og for at følge den kyniske vej. En mildere form for lærerholdning over for en studenter-kandidat er illustreret i K-3.

Havde det ikke varet almindeligt at høre Jesu ord som skarpe etiske formaninger, der kommer fra den myndige grundlægger af kristendommen, som træeder frem med guddommelig autoritet $\mathrm{i}$ de narrative evangelier, så ville det vittige $\mathrm{i}$ disse gensvar måske have fremkaldt et smil eller to. De spiller på den fornøjelige forvirring, der opstår gennem den overlagt forkerte brug af kategorier, og de antyder, at på et vist tidligt stadium i Jesus-bevægelsen kan et spøgefuldt gensvar have været tilstrækkeligt til at retfærdiggøre en ukonventionel praksis over for en mistænksom konvention.

\section{4. »Og hvad så?«-spørgsmålet}

Hvis denne tilgang til den historiske Jesus er på rette spor, og det tror jeg den er, dukker tre spørgsmål straks op og beder om en besvarelse. Det første er, om en sådan tale kunne have startet en bevægelse. Ville en sådan diskurs og aktivitet kunne have tiltrukket andre, der samlede sig, formede grupper og tog sig selv så alvorligt som Jesus-bevægelsen åbenbart gjorde? Det andet 
angår svælget mellem en Jesus af kynisk tilsnit og de noget senere mytologier om Jesus som den kosmiske Kristus og Guds Søn. Kan vi forklare, hvad der må være sket, for at komme fra den ene funderingsfigur til den anden? Og det tredje er, hvorvidt forskernes Jesus har nogen som helst chance for at blive accepteret som den historiske Jesus af kristne og andre i vor tid. Og i givet fald, hvad ville der ske med det billede af kristendommens oprindelse, som enhver af os er bestemt af, hvis vi alle måtte medgive, at den historiske Jesus snarere var noget $\mathrm{i}$ retning af en kynisk filosof end et guddommeligt menneske eller en inkarneret gud?

Jeg kan desværre ikke fremlægge hele diskussionen her, for hvert enkelt af disse spørgsmål kræver et temmelig detaljeret sæt af refleksioner. Men jeg vil gerne afslutte min forelæsning med at antyde, hvorledes jeg ville forsøge at besvare dem. Hvad det første spørgsmål angår, om en kynisk diskurs ville have forekommet attraktiv på den tid, så er svaret et utvetydigt ja. Den græsk-romerske æra var en tid præget af social fragmentering og kulturel opløsning. Kynikere, stoikere og mange andre udfordrede den enkelte til at leve mod strømmen i fors $ø$ get på at fastholde en fornemmelse af integritet ligesom Jesus gjorde det. Men så bliver jeg nødt til at fortælle jer, at den kyniske udfordring måske ikke var det eneste lokkemiddel, Jesus-bevægelsen havde. I denne forelæsning har jeg fremhævet de kyniske paralleller, fordi de er tydelige og tidlige. De bidrager også til at understrege forskellen mellem en sandsynlig historisk Jesus og evangeliernes mytiske Kristus. Der var imidlertid en forskel mellem kynikerne og Jesus-folket. Forskellen er tydelig i dannelsen af celler, grupper og små menigheder blandt Jesus-folket. Dette fænomen hænger sammen med det, som Jesus-folket kaldte Guds kongedømme, en social idé om nogen. Som man følger Jesus-skolernes udvikling ved at se på, hvorledes den kynisk-lignende udfordring blev transformeret til sociale koder, bliver en god dosis semitisk socialetik og ideologi mærkbar. Dette indebærer, at Jesus-bevægelsen fik sin energi fra en blanding af to robuste kulturer, som overstrømmede Levanten. Den var ikke blot genopdukkelsen af en traditionel græsk skoletradition. Den bragte den græske traditions fundament, den radikale individuelle appel, sammen med en helt igennem social forestilling om folkefællesskab, fundamentet $i$ den jødiske tradition. Denne kombination var genial og kan meget vel have åbnet for en entusiastisk kampplads for social og intellektuel eksperimenteren. 


\section{Jagten på den historiske Jesus}

Hvad det andet spørgsmål angår, svælget mellem de to Jesus-billeder, det ene historisk, det andet mytisk, må vi indse, at mytedannelse er en normal menneskelig aktivitet og særlig initiativrig i perioder med social og kulturel forandring. Ved ganske enkelt at følge Jesus-bevægelsens udvikling gennem det første århundrede kan det let påvises, hvorledes mytedannelse og social formation overalt gik hånd $\mathrm{i}$ hånd. Begge var eksperimenterende aktiviteter, som ofte første til overdrivelser. Men de gav også begge mening, når man betragter den sociale vision, som drev disse bevægelser, og den socialhistorie, som de gennemlevede. Ser vi nærmere efter, så kan vi fremanalysere logikken i dusinvis af myter, som de tidlige kristne undfangede på kritiske tidspunkter i deres sociale og intellektuelle historie. Disse myter havde kun lidt at gøre med den historiske Jesus, men meget at gøre med de energier, som disse folk investerede $\mathrm{i}$ deres nye sociale indretninger og med de påstande, som de fandt det nødvendigt at hævde for at retfærdiggøre deres bevægelser. Vi har muligvis brug for en begynderbog i græsk-romersk religion for at se, at de tidlige kristne mytologier overhovedet ikke var unaturlige set $\mathrm{i}$ lyset af de forestillingsverdener, som kendetegnede samtiden. Og vi har måske brug for en smule teori om mytedannelse, hvis vi ønsker at berolige vort sind om den lethed hvormed og den grund hvorfor disse tidlige kristne omformede en funderingsfigur til en gud. Men processen lader sig forklare, og der er hverken brug for mirakler eller mystifikationer for at kunne redegøre for den.

Hvad det sidste spørgsmål angår, hvorvidt den nye historiske Jesus vil have mulighed for at blive taget alvorlig af vor tids kristne, så er det for tidligt at udtale sig. At tage den historiske Jesus alvorligt måtte indebære en anerkendelse af evangelierne som kristne myter. At anerkende evangelierne som kristne myter måtte indebære, at deres logik blev blotlagt. At blotlægge de kristne evangeliers logik måtte indebære, at man engagerede sig i kulturkritik. Mens jeg er sikker på, at tiden er inde til en ærlig samtale om den kristne mytologis logik og om den afgørende forskel, som kristendommen har betydet og stadig betyder for det amerikanske samfund og verden, så spekulerer jeg på, om amerikanerne er modne til at lade dette ske. I må fortælle mig, om en Jesus af kynisk tilsnit vil kunne fungere i Skandinavien. Hvis vi alle begyndte at opfatte Jesus forskelligt fra evangeliernes billede af 


\section{Burton L. Mack}

ham, og hvis vor samtale blev ført i et offentligt samtalerum, så ville kulturkritikken i den vestlige verden aldrig blive den samme igen.

Jeg overlader det hermed til jeres overvejelse. Tak.

\section{Noter}

Den 20. maj 1996 holdt professor Burton L. Mack fra School of Theology at Claremont $i$ Californien en gæsteforelæsning på Det Teologiske Fakultet i Århus med titlen In Quest of the Historical Jesus. Det er denne forelæsning, som her bringes, oversat med noter og tilføjet en litteraturliste af Ole Davidsen.

1. Ordet pronouncement story, der i den engelsksprogede forskningstradition blev indført af Vincent Taylor som både oversattelse af og alternativ til formbistoriens begreber apoftegma (Rudolf Bultmann) og paradigme (Martin Dibelius), er her gengivet ved udsagnsfortalling. Herved forstås en fortalleform, som er kendetegnet ved, at det fortællende element er yderst kortfattet og kun tjener som baggrund for et pointeret udsagn af almen betydning.

2. Burton L. Mack citerer ikke direkte fra Lukasevangeliet, men anvender denne tekst som grundlag for sine rekonstruktioner. Han gengiver således formuleringerne i, hvad han betragter som deres på én gang mest pragnante og oprindelige form.

3. Også her er der tale om rekonstruktioner. Jeg har oversat Macks formuleringer så tæet p̊̊ den autoriserede danske oversattelse som muligt. Markante forskelle skyldes Macks alternative oversættelse af den græske tekst, jf. f.eks. J-10, hvor den danske oversættelse har »Menneske, hvem har sat mig til at dømme eller skifte mellem jer?»

4. DL henviser til Diogenes Laertius, Lives and Opinions of Eminent Philosophers in Ten Books, Loeb Classical Library, London 1972.

\section{Litteratur}

Borg, Marcus J., Jesus: A New Vision, 2. ed., San Francisco 1994.

Castelli, Elisabeth A. and Hal Taussig, eds., Reimagining Christian Origins. A Colloquium Honoring Burton L. Mack, Valley Forge 1996.

Mack, Burton L., A Myth of Innocence. Mark and Christian Origins, Philadelphia 1988.

Mack, Burton L., Rhetoric in the New Testament, Minneapolis 1990.

Mack, Burton L., The Lost Gospel. The Book of $Q$ \& Christian Origins, San Francisco 1993.

Mack, Burton L., Who Wrote the New Testament? The Making of the Christian Myth, San Francisco 1995.

Mack, Burton L. and Vernon Robbins, Patterns of Persuasion in the Gospels, Sonoma 1989. 


\section{Jagten på den historiske Jesus}

\section{Summary}

Burton L. Mack gives in this lecture an introduction to his work The Lost Gospel in which he points to the striking similarity between the historical Jesus and the cynic philosophers.

Burton L. Mack

Professor

School of Theology at Claremont

1325 N. College Avenue

Claremont, CA 91711-3199

USA 